\title{
Invention and Innovation: novelty and necessity
}

\author{
"You're a wave, met you on the shore \\ Though we've met before; \\ Keep coming back for more and more \\ Each day, you brighten up my eye; \\ Sparkle in your eye, star to steer me by"1
}

As oft-unheralded offspring of necessity, inventions may appear innocuously or glaringly on our horizon, adding new color to our world. Whether emerging a brilliant sunburst topping majestic clouds, or a subtle ray filtering through shadowy groves, inventions bring light to life and have the potential to forever change the previous world order. Serendipity and inspiration play their role in sparking the creative imagination; but inventions would barely see the light of day were it not for the persistence, perspiration and dogged determination that formed them while burning the proverbial midnight oil.

Actualization marks the subtle difference between invention and innovation. "Invention is the first occurrence of an idea for a new product or process, while innovation is the first attempt to carry it out into practice" ${ }^{\prime 2}$ According to Masnick, "plenty of people or companies who 'invented' an idea were never able to capitalize on the idea at all. It took others who actually innovated and built off that idea to make a product that actually had an impact on the world." ${ }^{3}$ In business terms, Invention is "the formulation of new ideas for products or processes;" Innovation is "all about the practical application of new inventions into marketable products or services." ${ }^{4}$ Schrage hits the nail on the head when he observes that "the technical excellence of an invention matters far less than the ... willingness of the customer or client to explore it." ${ }^{15}$ He continues: "We have no shortage of good inventions. What we need are better ways to bring them to customers." ${ }^{1}$ Innovation

\footnotetext{
'Lapeña JF. “You're a wave" [unpublished song] Manila: 1983

2Fagerberg J. (2004). "Innovation: A Guide to the Literature". in Fagerberg, Jan, David C. Mowery and Richard R. Nelson. The Oxford Handbook of Innovations. Oxford University Press. pp. 1-26.

${ }^{3}$ Masnick M. The Difference Between Innovation And Invention. Ramblings [serial on the internet] 2005 March 22 [cited 2009 May 18]; Available from:http://www.techdirt.com/ articles/20050322/1528251_F.shtml

${ }^{4}$ tutor $2 \mathrm{u}$ [website on the internet] Invention and Innovation [cited 2009 May 16]; Available from:http://tutor2u.net/business/production/invention-and-innovation.htm

${ }^{5}$ Schrage M. Much Ado about Invention. Technology Review published by MIT [serial on the internet] 2004 May [cited 2009 May 19]; Available from http://www.technologyreview. com/business/13595

${ }^{6}$ Davila T, Epstein MJ, Shelton R. (2006). Making Innovation Work: How to Manage It, Measure It, and Profit from It". Upper Saddle River: Wharton School Publishing.
}

involves creativity, but is not identical to it. According to Davila and others, "often, in common parlance, the words creativity and innovation are used interchangeably. They shouldn't be, because while creativity implies coming up with ideas, it's the "bringing ideas to life" . . . that makes innovation the distinct undertaking it is."

Our journal has a long and proud tradition of encouraging scholarly dissemination of discoveries. Far from being a purely academic exercise, making such novelty public is a necessary contribution to new knowledge, skills and attitudes of our readers. Rather than coming to rest in library shelves or databases, we hope these data and devices come alive in the minds, hearts and hands of physicians and surgeons, and are put to good use to ultimately benefit the patients, families and communities they serve. Never mind that we can ill-afford the costly and tedious processes of international patent application, or that our innovations seem "backward" from a "developed country" perspective; we hope they will be as relevant and appropriate as they are useful to our people and locoregional situation.

I am pleased and proud to announce that the Philipp $J$ Otolaryngol Head Neck Surg is now also indexed on Philippine Journals On Line (PhilJOL)available at $h t t p: / /$ www.philjol.info/ and supported by the International Network for the Availability of Scientific Publications (INASP) http://www.inasp.info/. This additional indexing service greatly increases our visibility and accessibility to such search engines as google and google scholar. Our journal is available on http://www.philjol.info/index.php/ PJOHNS/index. 